\title{
HUBUNGAN PEMAKAIAN PESTISIDA TERHADAP KADAR CHOLINESTERASE DARAH PADA PETANI SAYUR JENETALLASA-RUMBIA
}

\author{
RELATIONSHIP OF PESTICIDES ON BLOOD CHOLINESTERASE \\ LEVELS IN VEGETABLE FARMERS JENETALLASA-RUMBIA
}

\author{
Hardi $^{1^{*}}$, Muh.Ikhtiar ${ }^{2}$, Alfina Baharuddin ${ }^{2}$ \\ ${ }^{1}$ Program Studi Magister Kesehatan Masyarakat, Program Pasca Sarjana \\ Universitas Muslim Indonesia \\ ${ }^{2}$ Departemen Kesehatan Lingkungan, Program Pasca Sarjana \\ Universitas Muslim Indonesia \\ *email: hardi.hardismile@gmail.com
}

\begin{abstract}
Pesticides used by the community for its effectiveness in eradicating pests. However, WHO and UNEP note that there are 1.5 million cases of pesticide poisoning, most of which occur in developing countries with 20,000 fatal cases. Indonesia recorded that there were 771 cases of poisoning due to pesticides in 2016. Therefore, the purpose of this study was to analyze the relationship of pesticide use to blood cholinesterase levels in vegetable farmers. This research is an observational-quantitative study with cross sectional study design. The research data are the results of blood tests at BBLK, Makassar City from 30 respondents of vegetable farmers who were randomly selected using simple random sampling technique. The statistical analysis results showed that the frequency of spraying $(p=0.039)$, duration of spraying $(p=0.021)$, and length of service $(p=0.009)$. So it can be concluded that, there is a significant relationship between the frequency and duration of pesticide spraying and the working period with the blood colinesterase levels of vegetable farmers in Je'netallsa Village. So that farmers in Je'netallsa Village are advised to increase efforts to minimize the risk of exposure to pesticides by disciplining the application of SOPs for the use of safe pesticides and the proper use of PPE.
\end{abstract}

Keywords: pesticide, blood cholinesterase, farmer

\begin{abstract}
Abstrak
Pestisida banyak digunakan oleh masyarakat efektifitasnya dalam membasmi hama. Namun, WHO dan UNEP mencatat bahwa terdapat 1.5 juta kasus keracunan pestisida yang sebagian besar terjadi di negara berkembang dengan 20.000 kasus berakibat fatal. Indonesia mencatat terdapat 771 kasus keracunan akibat pestisida di tahun 2016. Oleh karena itu, tujuan penelitian ini untuk menganalisis hubungan pemakaian pestisida terhadap kadar cholinesterase darah pada petani sayur. Penelitian ini adalah penelitian observasional-kuantitatif dengan desain studi cross sectional. Data penelitian adalah hasil tes darah di BBLK, Kota Makassar dari 30 orang responden petani sayur yang dipilih secara acak menggunakan teknik simple random sampling. Hasil analisis statistik terhadap hubungan penggunaan pestisida dan kadar colinesterase darah menunjukkan frekuensi penyemprotan $(\mathrm{p}=0,039)$, lama penyemprotan $(\mathrm{p}=0,021)$, dan masa kerja $(\mathrm{p}=0,009)$. Sehingga dapat disimpulkan bahwa, terdapat hubungan yang signifikan antara frekuensi dan lama penyemprotan pestisida serta masa kerja dengan kadar colinesterase darah petani sayur di Desa Jenetallsa. Sehingga para petani di Desa Jenetallsa disarankan untuk meningkatkan upaya meminimalisisr resiko terpapar pestisida dengan cara disiplin dalam penerapan SOP penggunaan pestisida yang aman dan penggunaan APD yang tepat.
\end{abstract}

Kata kunci: pestisida, kadar colinesterase darah, petani

\section{PENDAHULUAN}

Indonesia merupakan negara agraris yang sebagian besar penduduknya hidup di pedesaan dan bermata pencaharian sebagai petani, sehingga pertanian merupakan sektor yang menyerap paling banyak tenaga kerja 
(Zulfani, dkk., 2017). Pestisida digunakan hampir di seluruh dunia dan digunakan dari pertanian yang kecil sampai pertanian yang besar di masyarakat desa dan kota untuk memberantas hama-hama domestik seperti, kecoak, semut, lalat, tikus, dan binatang pengganggu lainnya. Penggunaan pestisida oleh masyarakat dikarenakan harganya yang relatif murah, tahan, efektif untuk membasmi organisme pengganggu tanaman (Maranata, dkk., 2014). Namun, data WHO pada tahun 2017 menunjukkan bahwa kasus keracunan pestisida pada pekerja pertanian di negara berkembang sebanyak 18,2 per 100.000 petani di seluruh dunia dan lebih dari 168.000 orang meninggal setiap tahunnya. Menurut WHO, hal ini disebabkan rendahnya tingkat pendidikan dan pengetahuan petani terhadap cara penggunaan pestisida yang benar dan aman (Vitasari dan Cahyo, 2018).

Pestisida dapat masuk kedalam tubuh lewat inhalasi sehingga untuk mengetahui keracunan atau terpapar pestisida dalam tubuh diperlukan pemeriksaan kadar cholinesterase darah pada petani. Aktivitas cholinesterse darah adalah jumlah enzim cholinesterase aktif di dalam plasma darah dan sel darah merah yang berperan dalam menjaga keseimbangan sistem saraf. Kadar cholinesterase darah dapat terganggu ketika melakukan penyemprotan karena pestisida golongan organofosfat dan karbamat. Golongan pestisida tersebut akan mengikat enzim cholinesterase, sehingga cholinesterase menjadi tidak aktif dan menjadi akumulasi achethilcholin. Keadaan tersebut akan menyebabkan gangguan sistem saraf yang berupa peningkatan aktivitas cholinergic secara terus menerus akibat achethicholin yang tidak dihidrolisis. Ganggguan ini selanjutnya dikenal sebagai tanda atau gejala keracunan yang tidak hanya terjadi pada ujung syaraf tetapi juga dalam serabut syaraf.

Berdasarkan data Badan Pusat Statistik (BPS), produksi sayur dan buah di Propinsi Sulawesi Selatan sebesar 403.235 ton. Salah satu kabupaten dengan produksi sayuran terbanyak yaitu Kabupaten Je'neponto yaitu 2.624 ton dan mengalami peningkatan setiap tahunnya. Dalam upaya meningkatkan jumlah produksi sayuran tiap tahun dan mencegah tanaman agar tidak rusak karena hama dan penyakit, penggunaan pestisida dilakukan oleh para petani seperti halnya pada mayoritas petani di Desa Je'netallasa, Kecamatan Rumbia (Novianti, 2017).

Hasil observasi awal, diketahui bahwa mayoritas petani di Desa Je'netallasa tidak menggunkan Alat Pelindung Diri (APD) dalam melakukan penyemprotan pestisida. Lama penyemprotan, frekuensi penyemprotan, dosis penyemprotan, dan arah mata angin pun juga masih belum diperhatikan secara benar oleh para petani. Hasil wawancara pendahuluan juga menunjukkan bahwa aktivitas penyemprotan yang dilakukan oleh para petani di Desa Je'netallasa yaitu lebih dari tiga jam setiap harinya, hal ini menjadi indikasi kejadian keracunan pestisida pada para petani. Oleh karena itu, tujuan dari penelitian ini adalah untuk mengetahui hubungan pemakaian pestisida terhadap kadar cholinesterase pada petani sayur di Desa Jenetallasa, Kecamatan Rumbia, Kabupaten Jeneponto sehingga kejadian kercunan pestisida dapat dikendalikan.

\section{METODE PENELITIAN}

Penelitian ini merupakan penelitian observasional kuantitatif dengan rancang bangun cross sectional. Pengukuran kadar cholinesterase darah pada petani menggunakan pemeriksaan laboratorium. Lokasi penelitian ini di Desa Je'netallsa, Kecamatan Rumbia, Kabupaten Jeneponto. Penelitian ini dimulai dari 28 Agustus sampai dengan 30 Oktober 2019, dengan populasi sebanyak 60 orang yang berasal dari 3 kelompok tani. Jumlah sampel penelitian ini sebanyak 30 orang yang dipilih secara acak menggunakan teknik simple random smpling.

Alat ukur yang digunakan dalam penelitian ini adalah spektrofotometer untuk pemeriksaan tingkat kadar cholinesterase darah. Pengambilan sampel darah dilakukan oleh tenaga profesional dengan cara pengambilan sampel di ujung jari (jari telinjuk, jari tengah, atau jari manis) yang ditusuk dengan pen steril secara otomatis dengan volume sebanyak $0,01 \mathrm{cc}$. Variabel independen dalam penelitian ini meliputi penggunaan APD dan penggunaan pestisida (dosis pestisida, lama penyemprotan, masa kerja, dan frekuensi penyemprotan). Sedangkan untuk variabel dependen dalam penelitian ini adalah kadar cholinesterase 
darah pada petani sayur di Desa Jenetallsa, Kecamatan Rumbia, Kabupaten Jeneponto. Teknik analisis data yang digunakan dalam penelitian ini adalah analisis statistik Chiquare dengan nilai $\alpha=0,05$.

\section{HASIL DAN PEMBAHASAN}

\section{Penggunaan Alat Pelindung Diri}

APD (Alat Pelindung Diri) yang dipakai petani di Desa Jenetallsa, Kecamatan Rumbia, Kabupaten Jeneponto saat melakukan penyemprotan terdiri dari 7 jenis yaitu baju lengan panjang, celana panjang, masker atau penutup hidung, topi, kaca mata, kaos tangan, dan sepatu. Distribusi pemakaian APD pada petani dikategorikan menjadi 2 kategori yaitu: (1) Kategori lengkap apabila saat melakukan penyemprotan, petani memakai 4 atau lebih APD, dan (2) Kategori tidak lengkap apabila saat melakukan penyemprotan, petani memakai kurang dari 4 APD.

Tabel 1. Pemakaian APD pada Petani Sayur di Desa Jenetallasa, Kecamatan Rumbia, Kabupaten Jeneponto

\begin{tabular}{lcc}
\hline Penggunaan APD & $\mathrm{n}$ & $\%$ \\
\hline Tidak lengkap & 22,0 & 73,3 \\
Lengkap & 8,0 & 26,7 \\
\hline
\end{tabular}

Tabel 1 menunjukkan bahwa mayoritas petani sayur di Desa Jenetallasa, Kecamatan Rumbia, Kabupaten Jeneponto tidak menggunakan APD lengkap saat melakukan penyemprotan pestisida. Dari ketujuh jenis APD, mayoritas petani sayur tidak menggunakan masker dan kacamata saat melakukan penyemprotan pestisida. Alasan yang dikemukakan oleh mayoritas petani sayur tidak meggunakan APD tersebut karena dapat mengganggu proses pernapasan pada saat melakukan penyemprotan jika menggunakan masker dan mengganggu penglihatan jika menggunakan kacamata. Selain itu, mayoritas petani menganggap kacamata bukan sebagai salah satu APD dalam penyemprotan pestisida.

\section{Dosis Pestisida}

Dosis pestisida dalam penelitian ini dibedakan menjadi 2 kategori yaitu: (1) Penggunaan dosis sesuai aturan, memperhatikan penggunaan pestisida sesuai dengan prosedur yang tertera pada kemasan pestisida ( $<1,5 \mathrm{cc} /$ liter), dan (2) Penggunaan dosis tidak sesuai aturan, tidak memperhatikan prosedur yang tertera pada kemasan (>1,5 cc/liter).

Tabel 2. Dosis Pestisida yang Digunakan Petani Sayur di Desa Jenetallasa, Kecamatan Rumbia, Kabupaten Jeneponto

\begin{tabular}{lcr}
\hline Dosis Pestisida & $\mathrm{n}$ & $\%$ \\
\hline Tidak Sesuai Aturan & 15,0 & 50,0 \\
Sesuai Aturan & 15,0 & 50,0 \\
\hline
\end{tabular}

Tabel 2 menunjukkan bahwa masih ada petani sayur di Desa Je'netallsa, Kecamatan Rumbia, Kabupaten Jeneponto yang menggunakan dosis pestisida tidak sesuai aturan dalam membasmi hama dan penyakit tanaman sayur yaitu tidak memperhatikan prosedur yang tertera pada kemasan serta dosis $>1,5 \mathrm{cc} /$ liter.

\section{Lama Penyemprotan}

Lama penyemprotan merupakan jumlah waktu (jam) yang dihabiskan oleh petani sayur pada saat melakukan penyemprotan dalam satu hari. Variabel lama penyemprotan ini dikategorikan menjadi 2 kategori, yaitu: (1) >3-4 jam/hari, dan (2) $\leq 3-4 \mathrm{jam} / \mathrm{hari}$.

Tabel 3. Lama Penyemprotan Pestisida oleh Petani Sayur di Desa Jenetallasa, Kecamatan Rumbia, Kabupaten Jeneponto

\begin{tabular}{lrr}
\hline Lama Penyemprotan & $\mathrm{n}$ & $\%$ \\
\hline$>3-4$ jam/hari & 21,0 & 70,0 \\
$\leq 3-4$ jam/hari & 9,0 & 30,0 \\
\hline
\end{tabular}

Tabel 3 menunjukkan bahwa mayoritas petani sayur di Desa Jenetallasa, Kecamatan Rumbia, Kabupaten Jeneponto melakukan penyemprotan pestisida lebih dari 3-4 jam dalam satu hari. Hal ini mengindikasikan bahwa paparan pestisida pada petani sayur masih tinggi dan risiko untuk terpapar pestisida juga akan lebih lama karena mayoritas petani tidak menggunakan APD berupa masker sehingga risiko keracunan pestisida pada para petani sayur juga akan tinggi karen apestisida yang masuk ke dalam tubuh petani sayur melalui jaliur inhalasi atau pernafasan.

\section{Masa Kerja}

Masa kerja pada penelitian ini dibedakan menjadi 2 kategori, yaitu; (1) Kurang dari sama dengan 5 tahun $(\leq 5$ Tahun), dan (2) Lebih dari 5 tahun $(>5$ Tahun). 
Tabel 4. Masa Kerja Petani Sayur di Desa Jenetallasa, Kecamatan Rumbia, Kabupaten Jeneponto

\begin{tabular}{lrr}
\hline Masa Kerja & $\mathrm{n}$ & $\%$ \\
\hline 5 Tahun & 23,0 & 76,7 \\
$\leq 5$ Tahun & 7,0 & 23,3 \\
\hline
\end{tabular}

Tabel 4 menunjukkan bahwa mayoritas petani sayur di Desa Jenetallasa, Kecamatan Rumbia, Kabupaten Jeneponto telah bekerja menjadi petani sayur selama lebih dari 5 tahun. Hal ini dapat diindikasikan bahwa mayoritas petani sayur tersebut juga telah lebih dari 5 tahun terpapar pestisida. Kemungkinan terjadinya keracunan pestisida pada petani sayur juga semakin tinggi karena penggunaan APD oleh mayoritas petani sayur tidak lengkap terutama penggunaan masker untuk menghalangi pestisida masuk ke dalam tubuh melalui jalur pernafasan.

\section{Frekuensi Penyemprotan}

Frekuensi penyemprotan merupakan jumlah aktivitas penyemprotan pestisida yang dilakukan oleh petani sayur dalam wakrtu seminggu. Frekuensi penyemprotan ini dikategorikan menjadi 2 kategori, yaitu: (1) Lebih dari dua kali dalam seminggu ( $>2$ kali/minggu), dan (2) Kurang dari sama dengan 2 kali dalam seminggu $\quad(\leq 2$ kali/minggu).

Tabel 5. Frekuensi Penyemprotan Pestisida oleh Petani Sayur di Desa Jenetallasa, Kecamatan Rumbia, Kabupaten Jeneponto

\begin{tabular}{lrr}
\hline Frekuensi Penyemprotan & $\mathrm{n}$ & $\%$ \\
\hline$>2 \mathrm{kali} /$ minggu & 26 & 86,7 \\
$\leq 2 \mathrm{kali} /$ minggu & 4 & 13,3 \\
\hline
\end{tabular}

Tabel 5 menunjukkan bahwa mayoritas petani sayur di Desa Jenetallasa, Kecamatan Rumbia, Kabupaten Jeneponto sering melakukan penyemprotan pestisida dalam waktu satu minggu yaitu lebih dari 2 kali. Hal ini mengindikasikan bahwa paparan pestisida terhadap para petani sayur juga semakin sering dan risiko keracunan juga akan meningkat karena penggunaan APD oleh para petani sayur yang tidak lengkap, terutama penggunaan masker. Oleh karena itu, potensi masuknya pestisida saat petani sayur melakukan kegiatan penyemprotan pestisida juga akan semakin besar melalui jalur pernafasan.

\section{Hubungan Penggunaan Pestisida teradap Kadar Cholinesterase Darah Petani Sayur}

Hasil analisis hubungan penggunaan pestisida yang meliputi variabel dosis pestisida, lama penyemprotan, masa kerja, dan frekuensi penyemprotan terhadap kadar cholinesterase darah para petani sayur di Desa Jenetallasa, Kecamatan Rumbia, Kabupaten Jeneponto menunjukkan bahwa hanya terdapat 3 variabel yang memiliki nilai signifikan dengan $p$-value $<0,05$ yaitu lama penyemprotan, masa kerja, dan frekuensi penyemprotan sesuai pada Tabel 6 beriku:

Tabel 6. Analisis Hubungan Penggunaan Pestisidan terhadap Kadar Cholinesterase Darah Petani Sayur di Desa Jenetallasa, Kecamatan Rumbia, Kabupaten Jeneponto

\begin{tabular}{lr}
\hline Penggunaan Pestisida & $p$-value \\
\hline Lama Penyemprotan & 0,021 \\
Masa Kerja & 0,009 \\
Frekuensi Penyemprotan & 0,039 \\
\hline
\end{tabular}

Tabel 6 menunjukkan bahwa masa kerja petani sayuran memiliki pengaruh atau dampak yang sangat kuat terhadap kejadian keracunan pestisida pada petani sayur dibandingkan dengan variabel lainnya dengan nilai paling rendah yaitu 0,009 . Hal ini dikarenakan mayoritas petani sayur di Desa Jenetallasa, Kecamatan Rumbia, Kabupaten Jeneponto telah lama terpapar pestisida dengan masa kerja lebih dari 5 tahun.

\section{Hubungan lama penyemprotan dengan kadar cholinesterase}

Hasil uji statistik hubungan variabel lama penyemprotan di Desa Jenetallasa, Kecamatan Rumbia, Kabupaten Jeneponto menunjukkan hubungan yang signifikan dengan $\mathrm{p}$-value $<0,05$. Penelitian ini sejalan dengan penelitian yang dilakukan oleh Zulmi (2016) yaitu terdapat hubungan frekuensi dan lama penyemprotan serta interval kontak pestisida terhadap aktivitas cholinesterase petani. Penelitian ini juga didukung penelitian yang dilakukan oleh Lucki, dkk. (2018) yang menunjukkan bahwa lama penyemprotan pestisida oleh petani memiliki nilai rata-rata 2,5 jam, paling cepat 1 jam dan paling lama adalah 4 jam. Lama penyemprotan tergantung dari luas lahan yang dikerjakan petani. Petani 
yang melakukan penyemprotan selama 4 jam biasanya melakukan penyemprotan pada pagi hari dan sore hari. Menurut Permenaker No. Per-03/Men/1986 dalam Ningsih (2016) menyebutkan bahwa upaya untuk mencegah efek yang tidak diinginkan dari penggunaan pestisida, maka dianjurkan supaya tidak melebihi 4 jam/hari dalam seminggu berturut-turut. Tenaga kerja yang mengelola pestisida tidak boleh mengalami pemaparan lebih dari 5 jam sehari dan 30 jam dalam seminggu. Semakin lama penyemprotan yang dilakukan, maka paparan pestisida juga semakin tinggi sehingga berisiko terjadinya keracunan. Semakin lama melakukan penyemprotan, maka pestisida yang terpapar akan semakin banyak. Hal tersebut dapat mempengaruhi tubuh terkena atau masuknya pestisida sehingga dapat menyebabkan terjadinya keracunan.

Kebiasaan petani untuk beristirahat setelah melakukan penyemprotan juga dapat mengembalikan aktivitas cholinesterase dalam darah sehingga menjadi normal kembali. Penurunan kadar cholinesterase dalam plasma akan kembali normal dalam 3 minggu. Sedangkan dalam darah memerlukan waktu kurang lebih 2 minggu dengan tanpa paparan kembali. Kembalinya aktivitas cholinesterase tergantung sintesis enzim baru oleh organ hati. Teori dan jurnal yang telah mendukung tentang hubungan lama penyemprotan dengan kadar cholinesterase sangat erat hubungannya jadi dalam melakukan penyemprotan para petani harus memperhatikan lama waktu yang di gunakan pada saat melakukan penyemprotan untuk menghindari risiko keracunan pestisida.

\section{Hubungan masa kerja dengan kadar cholinesterase}

Hasil penelitian ini menunjukkan bahwa petani sayur di Desa Jenetallasa, Kecamatan Rumbia, Kabupaten Jeneponto yang memiliki masa kerja terlama yaitu selama 30 tahun dan 3 tahun merupakan masa kerja petani sayur yang paling terendah. Menurut beberapa pendapat bahwa semakin lama masa kerja maka semakin menurun tingkat cholisterase pada darah yang dapat mempengaruhi kesehatan salah satunya keracunan pestisida. Hasil analisis statistik dalam penelitian ini menunjukkan bahwa menunjukkan bahwa terdapat hubungan masa kerja terhadap kejadian keracunan pestisida yang ditandai dengan menurunnya kadar cholinesterase dengan nilai signifikansi $(0,009)$.

Penelitian ini didukung oleh hasil penelitian yang dilakukan Zuraida (2011) yang menyebutkan bahwa terdapat hubungan yang signifikan antara masa kerja dengan kadar cholinesterase darah dengan p-value $(0,000)$. Semakin lama masa kerja seorang petani maka semakin rendah kadar kolinesterase darah petani. Semakin lama petani menjadi penyemprot, kontak dengan pestisida pun akan semakin tinggi dan resiko keracunan pestisida pun akan semakin tinggi. Keracunan kronis lebih sulit dideteksi karena tidak segera terasa dan tidak menimbulkan gejala serta tanda yang spesifik. Namun, keracunan kronis dalam jangka waktu lama bisa menimbulkan gangguan kesehatan. Beberapa gangguan kesehatan yang sering dihubungkan dengan penggunaan pestisida diantaranya iritasi mata dan kulit, kanker, cacat pada bayi, serta gangguan saraf, hati, ginjal dan pernafasan. Pestisida yang masuk ke dalam tubuh dapat menumpuk dalam jaringan tubuh organisme (bioakumulasi).

Masa kerja petani yang sudah semakin lama melakukan kegiatan penyemprotan akan menimbulkan keracunan akibat keterpaparan pestisida yang semakin lama pula, sehingga jumlah racun pestisida yang masuk kedalam tubuh semakin menumpuk dan akan mempengaruhi kesehatan petani, dengan dampak keracunan yang perlahanlahan akan dirasakan petani, jadi diharapakan bagi para petani sudah lama melakukan penyemprotan agar sekiranya mengurangi kontak langsung dengan pestisida karena berakibat signifikan dengan keracunan pestisida.

\section{Hubungan frekuensi penyemprotan dengan kadar cholinesterase}

Frekuensi penyemprotan pestisida yang dilakukan oleh para petani sayur di Desa Jenetallasa, Kecamatan Rumbia, Kabupaten Jeneponto paling sering 3 kali penyemprotan pestisida dalam seminggu. Batas normal rata-rata penyemprotan pestisida satu minggu sebaiknya dilakukan 2 kali saja. Frekuensi penyemprotan yang terlalu sering bisa menyebabkan menurunnya kadar cholinesterase dalam darah. 
Hasil uji statistik pada penelitian ini menunjukkan bahwa terdapat hubungan antara frekuensi pestisida terhadap kadar cholinesterase darah petani sayur dengan pvalue $<0,05$ (Tabel 6). Hasil indepth interview pada petani sayur menjelaskan bahwa frekuensi penyemprotan pestisida yang dilakukan tergantung pada cuaca. Apabila pada musim hujan, maka frekuensi penyemprotan akan semakin meningkat karena pestisida akan sering tercuci oleh air hujan sehingga efektivitas pestisida dalam membunuh hama dan penyakit akan berkurang. Hasil penelitian ini sejalan dengan penelitian yang di lakukan oleh Lucki, dkk. (2018) yang menyatakan bahwa terdapat hubungan antara masa kerja, lama kerja, lama penyemprotan dan frekuensi penyemprotan terhadap kadar cholinesterase dalam darah pada petani di Desa Sumberejo, Kecamatan Ngablak, Kabupaten Magelang dengan $p$-value 0,026 . Semakin sering petani menggunakan pestisida, maka akan semakin besar pula untuk terjadinya keracunan pestisida tersebut. Paparan pestisida dengan frekuensi yang sering dan interval waktu yang pendek menyebabkan residu pestisida dalam tubuh manusia menjadi lebih tinggi. Akumulasi pestisida yang semakin lama dapat menimbulkan gejala keracunan pestisida.

Penelitian lain juga telah dilakukan oleh Zulmi (2016) mengenai hubungan antara frekuensi dan lama penyemprotan serta interval kontak pestisida dengan aktivitas cholinesterase petani. Hasil penelitian tersebut menunjukkan adanya hubungan antar variabel tersebut dengan nilai signifikansi secara berurutan yaitu 0,042 , 0,000 , dan 0,000 . Lama penyemprotan memiliki keeratan hubungan terkuat dengan kejadian keracunan pestisida yang ditandai dengan adanya penurunan pada kadar cholinesterase dengan nilai $-0,660$.

Selain lama penyemprotan, variabel lain (frekuensi penyemprotan dan interval kontak) memiliki kekuatan hubungan yang cukup kuat dengan melihat nilai korelasi 0,287 dan 0,594. Berdasarkan uraian tersebut, sebaiknya penggunaan pestisida dilakukan tepat waktu dan terjadwal, serta tidak lebih dari 3 kali penyemprotan dalam seminggu. Hal ini bertujuan agar frekuensi paparan pestisida terhadap petani sayur di Desa Jenetallasa, Kecamatan Rumbia, Kabupaten Jeneponto menjadi berkurang.

\section{KESIMPULAN DAN SARAN}

\section{Kesimpulan}

Variabel pemakaian pestisida yang meliputi lama kerja, masa kerja, dan frekuensi kerja memiliki hubungan yang signifikan terhadap kejadian keracunan pestisida yang ditandai dengan penurunan kadar cholinesterase darah pada para petani sayur di Desa Jenetallasa, Kecamatan Rumbia, Kabupaten Jeneponto. Lama penyemprotan mayoritas petani sayur lebih dari 3 jam/hari, masa kerja mayoritas petani sayur lebih dari 5 tahun, dan frekuensi penyemprotan pestisida lebih dari 2 kali dalam seminggu. Hal inilah yang kemudian yang menjadi risiko terjadinya keracunan pestisida pada petani sayur di Desa Jenetallasa, Kecamatan Rumbia, Kabupaten Jeneponto.

\section{Saran}

Saran yang dapat dirumuskan dari hasil penelitian ini adalah sebagai berikut:

a. Dinas kesehatan dan pertanian setempat sebaiknya bekerja sama untuk melakukan penyuluhan terkait kemanan penyemprotan dengan pestisida, pemeriksaan kadar cholinesterase bagi para petani 1 kali/tahun untuk mengetahui para petani yang ada indikasi keracunan, serta pemeriksaan residu pada tanah, air, dan sayuran untuk mendapatkan hasil pertanian yang baik dan sayuran yang layak konsumsi bagi masyarakat.

b. Pendampingan kepada para petani oleh kelompok tani dalam setiap kegiatan penjamahan lahan pertanian menggunakan pestisida agar para petani memperhatikan label pestisida yang meliputi informasi maupun teknis yang dilakukan di lapangan. Pada saat melakukan penyemprotan harus memakai APD lengkap dan mengurangi penyemprotan yang berlebihan yaitu kurang dari 3 jam penyemprotan/hari. 


\section{DAFTAR RUJUKAN}

1] Zulfania, KD., Setiani, O., Dangiran, HL. 2017. Hubungan Riwayat Paparan Pestisida Dengan Tekanan Darah Pada Petani Penyemprot Di Desa Sumberejo Kecamatan Ngablak Kabupaten Magelang. Jurnal Kesehatan Masyarakat. 5(3)

2] Maranata, R., Chahaya, I., Santi, DN. 2014. Perilaku Petani Dalam Penggunaan Pestisida Dan Alat Pelindung Diri (APD) Serta Keluhan Kesehatan Petani Di Desa Suka Julu Kecamatan Barus Jahe Kabupaten Karo. Jurnal Lingkungan dan Keselamatan Kerja, vol. 3, no. 3

3] Vitasari dan Suraji C. 2018. Hubungan Antara Pengetahuan Dan Sikap Dengan Praktik Pemakaian APD Masker Pada Petani Padi Saat Melakukan Penyemprotan Pestisida. Jurnal Ilmiah Permas. 8(1), 43-48

4] Novianti, PR., .2017. Analisis Risidu Pestisida Kloropirifos Pada Tomat Dengan Dan Tanpa Pencucian Di Desa Je'netallasa Kecamatan Rumbia Kabupaten Je'neponto. Skripsi.
Fakultas Kesehatan Masyarakat Universitas Hasanudin.

5] Lucki, F., Yusniar Hanani D., Yunita D, NA. 2018. Hubungan Masa Kerja, Lama Kerja, Lama Penyemprotan dan Frekuensi Penyemprotan Terhadap Kadar Kolinesterase Dalam Darah Pada Petani Di Desa Sumberejo, Kecamatan Ngablak, Kabupaten Magelang. Jurnal Kesehatan Masyarakat. 6(6)

6] Zulmi, N. 2016. Hubungan Antara Frekuensi Dan Lama Penyemprotan Dan Interval Kontak Pestisida Dengan Aktivitas Cholinesterase Petani Di Desa Kembangkuning Kecamatan Cepogo. Tesis. Universitas Muhammadiyah Surakarta

7] Ningsih, ER. 2016. Analisis Kuantitatif Perilaku Pestisida Ditanah. Yogyakarta: UGM Pres.

8] Zuraida. 2013. Faktor Yang Berhubungan Dengan Tingkat Keracunan Pestisida Pada Petani Di Desa Srimahi Tambun Utara Bekasi. Skripsi. Fakultas Kesehatan Masyarakat Universitas Indonesia. 